\title{
DETEKSI POLYMORPHISME DENGAN SUBSTITUSI NUKLEOTIDA TUNGGAL PADA Streptococcus agalactiae ISOLAT LOKAL INDONESIA
}

\author{
Angela Mariana Lusiastuti", Helga Seeger"), Desy Sugiani", Tatik Mufidah"), dan Hessy Novita") \\ "Balai Penelitian dan Pengembangan Budidaya Air Tawar \\ Jl. Raya Sempur No. 1, Bogor 16154 \\ E-mail: lusiastuti61@yahoo.co.id \\ ${ }^{\circ}$ Hessian State Laboratory Schubert Straße 60, H 13, 35396 Gießen, Germany
}

\begin{abstract}
ABSTRAK
Kasus penyakit pada budidaya ikan nila di wilayah di Jawa Barat, Jawa Tengah, Jawa Timur, Sulawesi Utara dan Papua Barat, disebabkan Streptococcus yang menyebabkan penyakit Streptococcosis di mana 80\% disebabkan oleh grup B S. agalactiae. Tujuan penelitian ini adalah melakukan deteksi pada nukleotida isolat S. agalactiae untuk mengetahui sampai sejauh mana terjadinya nukleotida polimorfisme tunggal (SNP) pada isolat tersebut. Identifikasi menggunakan PCR dilakukan terhadap $16 \mathrm{~S}$ rDNA dan primer spesifik spesies terhadap S. agalactiae yaitu agal I 5'-ATAAGAGTAATTAACACATGTTAG-3' (forward) dan agal II 5'-ACTTCGGGTGTTACAAAC-3'(reverse) dengan target 1250 bp. Produk PCR diamplifikasi terlebih dahulu menggunakan tujuh pasangan primer oligonukleotida yang berbeda yang didesain dari sekuens genom NEM316 GBS. Sekuens yang diperoleh dibandingkan dengan sekuens di Gene Bank database menggunakan National Center for Biotechnology Information Blast search tool. Hasil yang diperoleh ternyata ada dua basa yang berubah yaitu pada basa 24 dan basa 167. Pada basa 24 jelas terjadi subtitusi basa baru yaitu G, yang seharusnya tidak ada basa tersebut pada gen adhP-54 dan adhP-49 standar. Sedangkan pada basa 167 terjadi perbedaan basa dari seharusnya A pada standar menjadi G pada isolat 2.
\end{abstract}

KATA KUNCI: $\quad$ polimorfisme, Streptococcus agalactiae, PCR

ABSTRACT: The single strand conformational polymorphism to detect a nucleotide substitution in Streptococcus agalactiae isolate from Indonesia. By: Angela Mariana Lusiastuti, Helga Seeger, Desy Sugiani, Tatik Mufidah, and Hessy Novita

Cases of the disease in tilapia farming in West Java, Central Java, East Java, North Sulawesi and West Papua, is caused by Streptococcus species that cause disease Streptococcosis where $80 \%$ are caused by group B S.agalactiae. The purpose of this study was to detect the nucleotide S.agalactiae to determine the occurrence of single nucleotide polymorphisms (SNPS). Identification using 165 rDNA and species-specific primers of S.agalactiae were agal I 5'-ATAAGAGTAATTAACACATGTTAG-3 (forward) and agal II 5'-ACTTCGGGTGTTACAAAC -3' (reverse) with a target of $1250 \mathrm{bp}$. PCR products amplified using 7 different oligonucleotide primer pairs were designed from the genome sequences of GBS NEM316. Sequences obtained were compared with sequences in the Gene Bank database using the National Center for Biotechnology Information Blast search tool. The results showed there were two bases change on base 24 and base 167. At base 24 occured $G$ base substitution, which there should be no such bases in the gene and adhP-54 and adhP-49 standard. While there was a difference in base 167 should be a standard A to G in isolate 2.

KEYWORDS: $\quad$ polymorfism, Streptococcus agalactiae, PCR

\section{PENDAHULUAN}

Streptococcus sp. merupakan agen penyebab penyakit Streptococcosis pada ikan budidaya Bakteri ini mampu menginfeksi langsung ke dalam tubuh inang apabila terjadi kontak (Evans et al., 2006). Clark et al. (2000) menyatakan bahwa Streptococcosis di Filipina menyebabkan kematian ikan nila sekitar 50\% sejak bulan pertama dan meningkat menjadi $80 \%$ sampai pada akhir masa pemeliharaan dalam karamba.

Infeksi Streptococcus grup B dikaitkan dengan morbiditas dan kematian yang signifikan pada spesies ikan air tawar, estuaria dan laut. Patogenesis pada ikan menimbulkan septikemia dan kolonisasi pada berbagai organ, seperti mata, otak, ginjal dan usus; Tanda-tanda klinis muncul segera setelah infeksi termasuk depresi atau aksitabiliti, anoreksia, bentuk tubuh seperti huruf $\mathrm{C}$, berenang dan berputar-putar tak menentu, dan kematian pada ikan (Evans et al., 2002). Histopatologi menunjukkan septikemia dengan kerusakan mononuklear pada meninges, epikardium dan mata. Di mana peradangan terjadi pada hari ke-3 dan ke-7 setelah infeksi (Filho et al., 2009). Evans et al. (2006) 
menyatakan gejala klinis lain dari Streptococcosis adalah perut bengkak, lambung dan usus terisi dengan cairan gelatinous atau kekuning-kuningan dan pada beberapa ikan terjadi hemoragik kecil di mata, eksoptalmia dan kornea mata buram (opasiti), selain itu hati membesar, kongesti ginjal dan limpa, dan adanya cairan di rongga peritoneal. Ikan nila yang sakit menjadi lesu, berenang tak menentu dan menunjukkan kekakuan dorsal.

Berdasarkan hasil penelitian Lusiastuti et al. (2012), tipe $S$. agalactiae isolat lokal Indonesia adalah nonhemolitik dengan uji cAMPnegatif dan masuk dalam Lancefield grup B. Dari 6 isolat yang positif S. agalactiae, hanya isolat $1,3,4$ dan 6 saja yang mempunyai kesamaan $100 \%$ sekuens gen 16 S rDNA menggunakan BLASTN 2.2.1 S. agalactiae dari NCBI. Sedangkan isolat 2 dan 5 tidak 100\% kesamaannya karena mengalami polimorfisme nukleotida tunggal.

Polimorfisme adalah variasi urutan DNA yang terjadi ketika satu nukleotida (A, T, C, atau G) dalam urutan genom berubah. Istilah yang sering juga digunakan adalah nukleotida polimorfisme tunggal (single nucleotide polymorphisms, SNP). Hal ini disebut juga mutasi. Mutasi titik merupakan perubahan pada basa N dari DNA atau RNA. Mutasi titik relatif sering terjadi namun efeknya dapat dikurangi oleh mekanisme pemulihan gen. Mutasi titik dapat berakibat berubahnya urutan asam amino pada protein, dan dapat mengakibatkan berkurangnya, berubahnya atau hilangnya fungsi enzim. Teknologi saat ini menggunakan mutasi titik sebagai marker (disebut SNP) untuk mengkaji perubahan yang terjadi pada gen dan dikaitkan dengan perubahan fenotipe yang terjadi.

Tujuan penelitian ini adalah melakukan deteksi pada nukleotida isolat S. agalactiae untuk mengetahui sampai sejauh mana terjadinya polimorfismenukleotida tunggal (SNP) pada isolat tersebut.

\section{BAHAN DAN METODE}

Sampel berasal dari ikan nila Oreochromis niloticus yang terinfeksi dengan gejala klinis berenang tidak beraturan (whirling), eksopthalmia (pop eye), warna tubuh kehitaman dan adanya hemoragi eksternal pada anus dan di beberapa tempat pada tubuh. Isolat diperoleh dari otak, ginjal anterior, mata dan hati yang dikultur pada 5\% Columbia sheep blood agar (Oxoid, Wernigerode, Germany) pada suhu $32^{\circ} \mathrm{C}$ (Evans et al., 2002).

Semua isolat yang diduga isolat S. agalactiae Grup B (GBS) diuji biokimiawi dengan metode hemolisis dan uji cAMP (MacFaddin, 2000). Hasil dari Voges Proskauer dan fermentasi sorbitol, trehalose, ribose, inulin, mannose, xylose dan lactose dianalisis lebih lanjut dengan menggunakan API 20 Strep System (bioMerieux, France). Tipe B antisera (Oxoid) dikelompokkan berdasarkan grup Lancefield.

Identifikasi menggunakan PCR dilakukan terhadap 16S rDNA dan primer spesifik spesies terhadap S. agalactiae yaitu agal I 5'ATAAGAGTAATTAACACATGTTAG-3' (forward) dan agal II 5'-ACTTCGGGTGTTACAAAC-3' (reverse) dengan target $1250 \mathrm{bp}$. Kondisi cycling yang digunakan adalah $95^{\circ} \mathrm{C}$ selama 5 menit, diikuti denaturasi 35 siklus pada $94^{\circ} \mathrm{C}$ selama satu menit, annealing pada $50^{\circ} \mathrm{C}$ satu menit dan extension pada $72^{\circ} \mathrm{C}$ selama 7 menit, diikuti final extension pada $72^{\circ} \mathrm{C}$ selama 7 menit. Produk PCR kemudian dielektroforesis menggunakan 12 $\mu \mathrm{L}$ amplicon dalam 2\% agarose gel (Biozym, HessischOldendorf, Germany) pada 120 Volt dalam $1 \mathrm{x}$ Trisacetate-electrophoresis buffer (TAE) $[(0,04 \mathrm{~mol} / \mathrm{L}$ Tris, 0,001 mol/L EDTA; pH 7.8)]. Marker yang digunakan adalah GeneRuler 100 bp DNA ladder (MBI Fermentas).

Produk PCR dari sampel positif hasil identifikasi PCR di atas kemudian diuji berdasarkan skema Multi Locus Sequence Typing (MLST) terhadap 7 loci yaitu: alcohol dehydrogenase gbs0054 (adhP), phenylalanyl tRNA synthetase (pheS), amino acid transporter gbs0538 (atr), glutamine synthetase $(g \ln A)$, serine dehydratase gbs2105 ( $s d h A)$, glucose kinase gbs0518 (glcK), dan transketolase gbs2105 (tkt). Produk PCR diamplifikasi terlebih dahulu menggunakan tujuh pasangan primer oligonukleotida yang berbeda seperti tersebut di atas yang didesain dari sekuens genom NEM316 GBS. Adapun amplifikasi PCR adalah sebagai berikut: $50 \mu \mathrm{L}$ campuran dari $5 \mu \mathrm{L}$ sampel DNA, $20 \mathrm{pmol} / \mu \mathrm{L}$ primer PCR (TIB MOLBIOL Syntheselabor, Berlin, Germany), 1x PCR buffer 1,5 mM MgCl2 (Qiagen, Hilden, Germany), $0.5 \mu \mathrm{L}$ Taq DNA polymerase (Qiagen), dan 1,6 mM deoxynucleoside triphosphate mix (dNTPs, ABgene, Epsom, United Kingdom). Kondisi cycling yang digunakan adalah denaturasi awal pada $94^{\circ} \mathrm{C}$ selama satu menit, primer annealing pada $55^{\circ} \mathrm{C}$ selama 45 detik, dan extension pada $72^{\circ} \mathrm{C}$ selama satu menit untuk 35 cycles. Produk PCR dielektroforesis dan dimurnikan menggunakan Microelute Cycle Pure Kit (Omega Bio-tek) dan disekuens di Gottingen Laboratories. Sekuens yang diperoleh dibandingkan dengan sekuens di Gene Bank database menggunakan National Center for Biotechnology Information Blast search tool.

\section{HASIL DAN BAHASAN}

Berdasarkan hasil pengujian dengan menggunakan uji cAMP, hemolisis dan API 20 STREP System maka ada dua isolat yaitu isolat 2 dan isolat 5 yang mempunyai tingkat kemiripan dengan S. agalactiae sebesar 79,3\% dan $89,8 \%$ Taxa yang signifikan berdekatan dengan $S$. agalactiae dengan kemiripan 79,3\% dan 89,8\% adalah Streptococcus acidominimus. Sedangkan isolat yang lain yaitu isolat 1, 3, 4, dan 6 mempunyai tingkat kemiripan dengan S. agalactiae sebesar 99,8\% sampai $100 \%$.

Berdasarkan data sekuens gene dari NCBI Blast, maka untuk isolat $1,3,4$, dan 6 diperoleh query coverage sebesar 97\% dan maksimum identifikasi $98 \%$ dideskripsikan sebagai S. agalactiae NEM316 (accession number gi123094426AL766843.1) dan merupakan genom yang lengkap. Isolat 2 dan 5 memperoleh query 
coverage yang rendah yaitu $76 \%$ tetapi maksimum identifikasinya sebesar 99\% dan dideskripsikan sebagai S. agalactiae strain GBS267 alcohol dehydrogenase (adhP) pseudogene, sekuens parsial (accession numbergi1224925311 FJ719775.1).

Untuk mengetahui lebih lanjut mengapa pada isolat 2 dan 5 mempunyai query coverage yang rendah tetapi tetap teridentifikasi sebagai $S$. agalactiae maka dilanjutkan dengan melihat internal fragmennya isolat 2. Internal fragmen dari isolat 2 dibandingkan dengan internal fragmen standard dari gen adh P-54 dan adhP49 yang dilakukan melalui multiple sequence alignment menggunakan program Clustal W2. Hasil yang diperoleh ternyata ada dua basa yang berubah yaitu pada basa 24 dan basa 167 . Pada basa 24 jelas terjadi subtitusi basa baru yaitu $G$, yang seharusnya tidak ada basa tersebut pada gen adhP-54 dan adhP-49 standar. Sedangkan pada basa 167 terjadi perbedaan basa dari seharusnya A pada standar menjadi $G$ pada isolat 2. Pada Tabel 1 menunjukkan contoh kelainan penyakit pada manusia jika terjadi mutasi DNA, dan jika hal ini terjadi pada S. agalactiae maka kemungkinannya adalah timbulnya gejala klinis yang berbeda dari $S$. agalactiae yang sejati. Menurut pendapat Shehaan et al. (2009), bahwa terdapat S. agalactiae biotipe 1 dan biotipe 2 . Kemungkinan lain adalah $S$. agalactiae dengan tipe sekuens yang sama atau serumpun dengan S. agalactiae pada sapi dan manusia. Tetapi hal ini memerlukan penelitian yang lebih lanjut.

Menurut Clancy (2008), polimorfisme biasanya terjadi akibat subtitusi nukleotida tunggal atau disebut juga single nucleotide polymorphism (SNP) yang merupakan variasi sekuens DNA yang terjadi ketika ada nukletioda tunggal atau satu nukleotida A, T, C atau G di dalam genom yang berbeda dengan suatu spesies biologis dalam hal ini adalah bakteri S. agalactiae. Menurut Clancy (2008), penyakit sickle-cell anemia pada manusia disebabkan perubahan genetik yang relatif kecil yang terjadi akibat kerusakan pada nukleotida tunggal pada rantai beta dari protein hemoglobin. Sehingga hal ini menyebabkan gen dari hemoglobin normal berubah menjadi gen hemoglobin sickle-cell. Adanya perubahan yang terjadi hanya pada satu nukleotida saja tetapi dapat memberikan dampak yang buruk. Beta hemoglobin (beta globin) adalah rantai tunggal dengan 147 asam amino. Sickle-cell anemia disebabkan oleh gen beta globin yang bermutasi yaitu hanya mutasi satu basa saja sehingga harusnya asam amino keenam adalah asam glutamik menjadi asam amino valin menyebabkan sel darah berbentuk seperti sickle (batang) yang saling melekat satu sama lain, sehingga tidak dapat mengangkut oksigen dengan baik yang berakibat suplai oksigen tidak lancar sehingga menyebabkan serangan jantung atau stroke (Clancy, 2008).

Menurut Twyman (2003), mutasi didefinisikan sebagai adanya perubahan pada sekuens DNA, yang disebut juga istilah single nucleotide polymorphism (SNP) untuk menjelaskan adanya perubahan satu pasang basa pada suatu populasi. Polimorfisme dapat terjadi pada setiap lokasi genetik dan sedikitnya dapat ditemukan pada dua sekuens yang berbeda, yaitu setiap sekuens yang muncul pada sedikitnya satu persen dari populasi. Lebih jauh, cut off prevalensi minimal 1\% diklasifikasikan sebagai polimorfisme dan jika frekuensinya lebih kecil dari 1\% maka alel dianggap mengalami mutasi (Twyman, 2003).

Menurut International Human Genome Sequencing Consortium (2001), SNP biasanya sebagai marker untuk menentukan populasi organisme yang mengalami perubahan genetik sehingga menjadikan individu membawa sifat tertentu termasuk menderita suatu penyakit. DNA terganggu akibat terpapar faktor lingkungan seperti bahan kimia dan radiasi ultraviolet pada waktu proses replikasi. Tabel 1 menyajikan contoh tipe mutasi DNA yang mengakibatkan kelainan penyakit pada manusia.

Mutasi dapat dihasilkan dari kejadian yang disebut sebagai crossing-over selama proses meiosis. Hal ini dapat terjadi pada beberapa area dari genom yang sering disebut sebagai hot pots di mana sekuens mengalami pengulangan berkali-kali. Sebagai contoh, sekuens pengulangan trinukleotida pada saat replikasi DNA karena polymerase dapat mengalami "slip" disassosiasi dan reassosiasi dengan untai DNA (Viguera et al., 2001).

Pada kasus yang lain, mutasi dapat terjadi dengan cara karena adanya insersi atau terhapusnya satu basa. Hal ini disebut frameshift mutations, di mana keseluruhan protein akan berubah sebagai akibat terjadi penghapusan atau insersi. Hal ini terjadi karena nukleotida dibaca oleh ribosom dalam bentuk grup tiga basa yang disebut kodon. Jadi, jika basa terhapus atau diinsersi dari gen yang tidak terdiri dari tiga basa, maka reading frame yang tersisa dari protein tersebut akan dibuang.

Faktor-faktor yang dapat menyebabkan mutasi antara lain adalah terpapar ultraviolet (UV) dari cahaya matahari. Salah satu akibat terpapar UV adalah hidrolisis basa sitosin menjadi bentuk hidrat yang menyebabkan basa tersebut salah berpasangan dengan adenin dan pada replikasi berikutnya posisinya diganti oleh timin (Viguera et al., 2001). Penyebab lain adalah terpapar bahan kimia seperti Oxidizing agents yang umum disebut sebagai radikal bebas di mana bahan ini dapat memodifikasi nukleotida sehingga merubah pasangan basa. Mutasi juga dapat terjadi secara spontan, misalnya depurinasi di mana basa purin hilang dari nukleotida melalui proses hidrolisis. Deaminasi atau hilangnya grup amin dari basa juga dapat terjadi.

Adanya perbedaan dalam sekuens $S$. agalactiae isolat lokal Indonesia ditunjang dengan penelitian Sheehan et al. (2009) yang melaporkan bahwa isolat S. agalactiae dari ikan nila, Oreochromis niloticus menunjukkan dua karakter kluster yang berbeda berdasarkan variasi di 


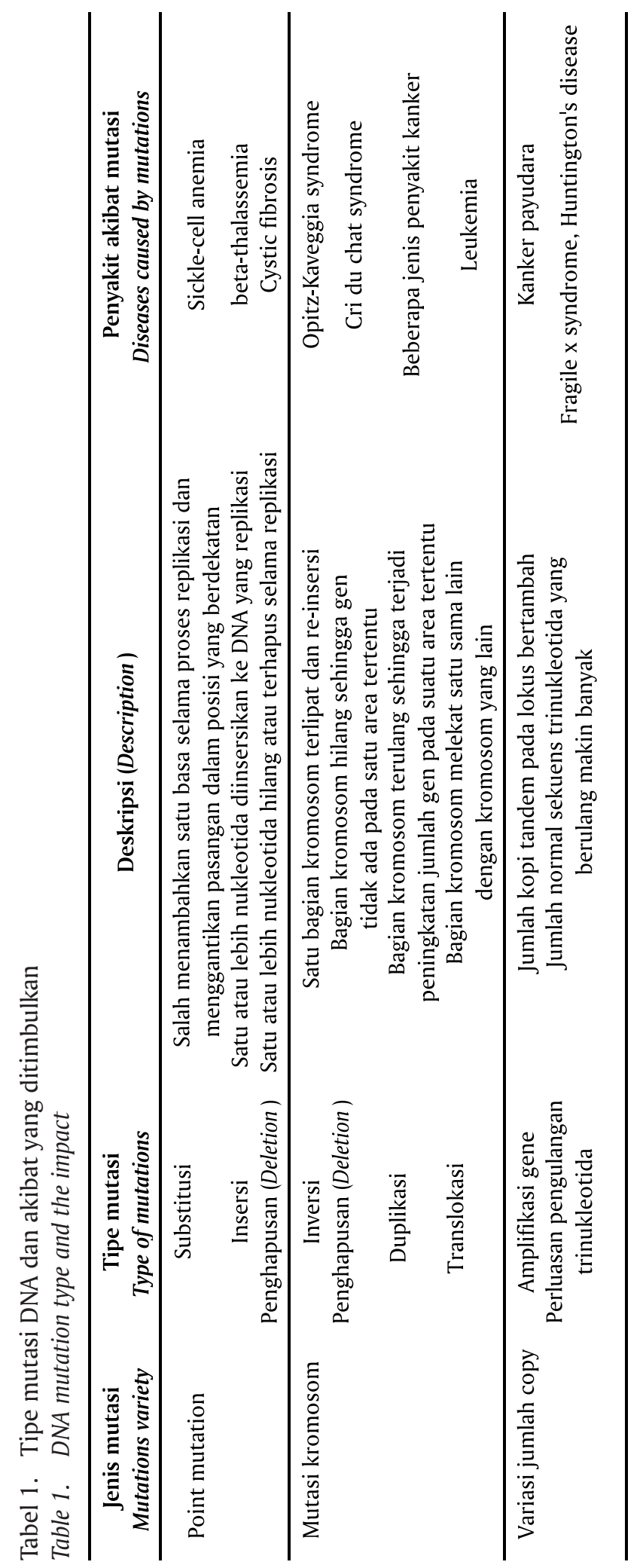


dalam propertis biokimiawi dan fenotipiknya sebagai contoh karakteristik hemolitik. Lebih lanjut Sheehan et al. (2009) menyatakan bahwa perbedaan kluster atau biotipe itu dibagi menjadi S. agalactiae beta-hemolitik atau klasik atau S. agalactiae biotipe 1 dan S. agalactiae non-beta-hemolitik atau S. agalactiae biotipe 2. S. agalactiae biotipe 1 menginfeksi keseluruhan siklus produksi dari benih sampai pembesaran, sedangkan $S$. agalactiae menginfeksi pada ikan konsumsi. Sheehan et al. (2009) juga melaporkan bahwa S. agalactiae biotipe 2 lebih umum dijumpai di Asia (Cina, Indonesia, Vietnam, dan Filipina).

\section{KESIMPULAN}

Isolat 1, 3, 4 dan 6 diperoleh query coverage sebesar 97\% dan maximum identifikasi 98\% dideskripsikan sebagai S. agalactiae NEM316 (accession number gi123094426AL766843.1) dan merupakan genom yang lengkap. Isolat 2 dan 5 memperoleh query coverage yang rendah yaitu $76 \%$ tetapi maksimum identifikasinya sebesar 99\% dan dideskripsikan sebagai S. agalactiae strain GBS267 alcohol dehydrogenase (adhP) pseudogene, sekuens parsial (accession number gi1224925311 FJ719775.1). Ada dua basa yang berubah yaitu pada basa 24 dan basa 167. Basa 24 terjadi subtitusi basa baru yaitu $G$, yang seharusnya tidak ada basa tersebut pada gen adhP-54 dan adhP-49 standar. Basa 167 terjadi perbedaan basa dari seharusnya A pada standar menjadi $G$ pada isolat 2 .

\section{DAFTAR ACUAN}

Clancy, S. (2008). Genetic mutation. Nature Education, $1(1)$.

Clark, J.S., Paller, B., \& Smith, P.D. (2000). Prevention of Streptococcus in tilapia by Vaccination. The Philippine Experience. Camrose1@hotmail.com.

Evans, J.J., Klesius, P.H., Gilbert, P.M., Shoemaker, C.A., Al-Sarawi, M.A., Landsberg, J., Duremdez, R., AlMarzouk, A., \& Al-Zenki, S. (2002). Characterization of ß-haemolytic group B Streptococcus agalactiae in cultured seabream, Sparus auratus (L.,), and wild mullet, Liza klunzingeri (Day), in Kuwait. Journal of Fish Disease, 25, 505-513.

Evans, J.J., Pasnik, D.J., Klesius, P.H., \& Al-Ablani, S. (2006). First report of Streptococcus agalactiae and Lactococcus garviae from a wild bottlenose dolphin (Tursiops truncates). Journal of Wildlife Disease, 42, 561-569.

Filho, C.I., Muller, E.E., Pretto-Giordano, L.G., Paula, A., \& Bracarense, F.R.L. (2009). Histological findings of experimental Streptococcus agalactiae infection in nile tilapias (Oreochromis niloticus). Braz. J. Vet. Pathol., 2(1), 12-15.

International Human Genome Sequencing Consortium. (2001). Initial sequencing and analysis of the human genome. Nature, 409, 860-921.

Lusiastuti, A.M., Seeger, H., \& Zschoeck, M. (2012). Penyiapan isolat Streptococcus agalactiae untuk deteksi multilocus sequence typing system. Seminar Bioteknologi Universitas Diponegoro. Semarang, 6 Oktober 2012.

MacFaddin,J.F. (2000). Biochemical tests for identification of medical bacteria, $3^{\text {rd }}$ eds. Phildelphia, PA. Lippincot Williams and Wilkins.

Sheehan, B., Lee, Y.S., Wong, F.S., Chan, J., Labrie, L., Komar, C., Wendover, N., \& Grisez, L. (2009). Streptococcosis in tilapia: A more complex problem than expected. World Aquaculture Meeting 2009.

Twyman, R. (2003). Mutation or polymorphism? Wellcome Trust website, http://genome.wellcome. ac.uk/doc_WTD020780.html (2003).

Viguera, E., Cancell, D., \& Ehrlich, S.D. (2001). Replication slippage involves DNA polymerase pausing and dissociation. EMBO Journal, 20, 25872595. 
